\title{
NMDA Currents and Receptor Protein Are Downregulated in the Amygdala during Maintenance of Fear Memory
}

\author{
Fatiha Zinebi, ${ }^{1}$ Jiangang Xie, ${ }^{1}$ Jie Liu, ${ }^{1}$ Rex T. Russell, ${ }^{2}$ Joel P. Gallagher, ${ }^{1}$ Margaret G. McKernan, ${ }^{3}$ and \\ Patricia Shinnick-Gallagher ${ }^{1}$ \\ ${ }^{1}$ University of Texas Medical Branch, Department of Pharmacology and Toxicology, Galveston, Texas 77555-1031, 2Department of Anesthesiology, Johns \\ Hopkins University, Baltimore, Maryland 21205, and ${ }^{3}$ Department of Radiology, Wake Forest University Baptist Medical Center, Winston-Salem, North \\ Carolina 27157-1088
}

The amygdala plays a critical role in fear conditioning, a model of emotional learning and cue-induced anxiety. In the lateral amygdala, fear conditioning is associated with an enduring increase in synaptic strength mediated through AMPA receptors and with a reduction in paired-pulse facilitation, reflecting an increased probability of neurotransmitter release. Here we show that NMDA-mediated transmission in the thalamic-to-lateral amygdala pathway is not facilitated after fear conditioning, although probability of transmitter release is enhanced. Rather, the $\mathrm{EC}_{50}$ for NMDA receptor (NR)-mediated current is shifted threefold to fourfold to the right in fear-conditioned animals, suggesting a postsynaptic alteration in NMDA receptors in the maintenance phase of fear memory. Furthermore, the ability of nonselective and subunit-selective antagonists of NMDA receptors to block NMDA receptor-mediated EPSCs is reduced in lateral amygdala neurons from fear-conditioned animals, suggesting a reduction in NMDA receptors at thalamolateral amygdala synapses. In addition, Western blots show a reduction in phosphorylated-NR1, NR2A, and NR2B subunit protein expression in amygdalas from fearconditioned animals. These data indicate that postsynaptic mechanisms are involved in synaptic plasticity in the thalamoamygdala pathway in fear conditioning and raise the possibility that: (1) downregulation of the NMDA receptor may protect against excitotoxicity of unchecked NMDA receptor recruitment during induction and consolidation of fear memories, (2) reduced NMDA current and protein may allow persistence of the "capacity to reactivate" amygdala pathways in NMDA receptor-dependent fear memories, or (3) a persistent long-term depression of NMDA transmission may occur after fear learning.

Key words: amygdala; synaptic plasticity; fear conditioning; fear-potentiated startle; memory; learning; NR subunits; ifenprodil; pairedpulse facilitation

\section{Introduction}

Excitatory synaptic transmission, mediated through glutamate activation of AMPA, kainate, and NMDA receptors, is essential for much of the learning-induced synaptic plasticity that occurs in the brain. NMDA receptors (NRs) are heteromeric ion channels composed of NR1 and NR2 subunits and sometimes NR3 subunits (Cull-Candy et al., 2001). The NR2 subunits include NR2A-NR2D, which, along with NR1, confer distinct functional properties on NMDA receptors (Monyer et al., 1994; Lau and Huganir, 1995; Kohr and Seeburg, 1996; Rostas et al., 1996; CullCandy et al., 2001). The induction and maintenance phases of most forms of synaptic plasticity in vitro are phenomena mediated through different molecular pathways and are thought to be membrane mechanisms underlying learning and memory. NMDA receptors are of crucial importance in the induction of long-term potentiation (LTP) (Nicoll and Malenka, 1995, 1999; Bear, 1996), but the strength of NMDA receptor-mediated trans-

Received June 4, 2003; revised Sept. 17, 2003; accepted Sept. 19, 2003.

This work was supported by National Institutes of Health Grants MH58327 and F30 MH11221. We thank Drs. Geoff Swanson and Jim Blankenship and Brad Schroeder for their helpful comments on this manuscript.

Correspondence should be addressed to Dr. Patricia Shinnick-Gallagher, Department of Pharmacology and Toxicology, University of Texas Medical Branch, Galveston, TX 77555-1031. E-mail: psgallag@utmb.edu.

Copyright $\odot 2003$ Society for Neuroscience $\quad 0270-6474 / 03 / 2310283-09 \$ 15.00 / 0$ mission during the maintenance of LTP is generally changed to a lesser degree than that mediated through AMPA receptors (Errington et al., 1987; Kauer et al., 1988; Muller et al., 1988; Nicoll and Malenka, 1995).

NMDA receptors are also necessary for behavioral synaptic plasticity. Studies consistently show that NMDA receptors in the amygdala are required during the acquisition (induction or training) phase of fear conditioning (Davis, 1992; Lavond et al., 1993; Rodrigues et al., 2001), but the role of NMDA receptors during the expression of fear memory is less clear. A number of studies, using different experimental paradigms and measures of fear, found that blocking NMDA receptors before testing disrupts the expression of conditioned fear responses (Lee and Kim, 1998; Fendt, 2001; Lee et al., 2001) and suggest that the effectiveness of NMDA receptor antagonists in preventing expression of conditioned fear may be attributable to an inhibition of NMDA receptors used in normal synaptic transmission. Other evidence indicates that NMDA receptor antagonists do not block expression of fear conditioning (Miserendino et al., 1990; Campeau et al., 1992; Maren et al., 1996; Gewirtz and Davis, 1997; Walker and Davis, 2000), whereas other data suggest that induction and expression of fear conditioning involve specific NMDA receptor subunits (Rodrigues et al., 2001). These findings indicate a lack of consen- 
sus regarding the function of NMDA receptors in the expression of fear learning.

Behavioral fear conditioning is associated with synaptic strengthening (McKernan and Shinnick-Gallagher, 1997; Rogan et al., 1997) of AMPA receptor-mediated EPSCs in the lateral amygdala and a reduction in paired-pulse facilitation (PPF) (McKernan and Shinnick-Gallagher, 1997), an effect reflecting enhanced probability of neurotransmitter release at the thalamicto-lateral amygdala synapse; however, the fate of NMDA receptors after fear conditioning is not known.

The purpose of the present experiments was to test whether NMDA receptor-mediated transmission is altered after fear conditioning. The results showed that NMDA receptor-mediated synaptic transmission is downregulated in the lateral amygdala in the maintenance of fear memory.

\section{Materials and Methods}

Slice preparation. Male Sprague Dawley rats (4-6 weeks of age) (Harlan, Indianapolis, IN) were decapitated, and brains were rapidly removed and placed into cold oxygenated $\left(95 \% \mathrm{O}_{2}, 5 \% \mathrm{CO}_{2}\right)$ artificial CSF (ACSF) of the following composition (in $\mathrm{mM}$ ): $117 \mathrm{NaCl}, 3 \mathrm{KCl}, 1.2 \mathrm{MgCl}_{2}, 2.5$ $\mathrm{CaCl}_{2}, 1.2 \mathrm{NaH}_{2} \mathrm{PO}_{4}, 25 \mathrm{NaHCO}_{3}$, and 11 glucose. Coronal slices of 400 $\mu \mathrm{m}$ thickness were cut with a Vibroslice (Campden Instruments, London, UK) and left to adapt to room temperature for $1 \mathrm{hr}$ in oxygenated ACSF. The slices were then transferred to the recording chamber, where they were fully submerged, continuously superfused with ACSF at a flow rate of $1.5 \mathrm{ml} / \mathrm{min}$ (chamber volume $\approx 1 \mathrm{ml}$ ), and maintained at $33 \pm$ $1^{\circ} \mathrm{C}$. Magnesium was omitted in $\mathrm{Mg}^{2+}$-free solution.

Electrophysiology. Patch pipettes were pulled with a Flaming-Brown Model P80 micropipette puller (Sutter Instruments, Novato, CA) from a glass capillary ( $1.13 \mathrm{~mm}$ inner diameter; $1.5 \mathrm{~mm}$ outer diameter) to a tip resistance of 3-5 M $\Omega$ when filled with internal solution. The composition of the internal solution was (in mM): 115 Cs-gluconate, 1 EGTA, 0.3 $\mathrm{CaCl}_{2}, 2 \mathrm{MgCl}_{2}, 5 \mathrm{Na}-\mathrm{ATP}, 0.4 \mathrm{Na}-\mathrm{GTP}$, and 10 HEPES; $\mathrm{pH}$ was adjusted to 7.2 with $\mathrm{CsOH}$, and the final osmolarity was adjusted to $280 \mathrm{mOsm}$ by adding sucrose. An Axopatch 2A amplifier (Axon Instruments, Union City, CA) was used for voltage- and current-clamp recordings. Current signals were filtered at $1 \mathrm{kHz}$ with a four-pole low-pass Bessel filter and digitized (Digidata 1200; Axon Instruments) at 5 or $10 \mathrm{kHz}$ for computer storage. Data were acquired and analyzed with pClamp 8.01 software (Axon Instruments).

Bipolar stimulating electrodes $(50 \mathrm{k} \Omega$ ) insulated to the tip were placed on afferents that emerge from the internal capsule, originate in the thalamus, and project monosynaptically (latency of $<3 \mathrm{msec}$ ) to the lateral nucleus of the amygdala (LA) (LeDoux et al., 1985) (see Fig. 1A). Other afferent fibers may also course through this area (MacDonald, 1998), but the conventional term "thalamic" was used here to designate this input in the slice. Synaptic responses were elicited by applying square wave pulses of $150 \mu$ sec duration and variable intensities, typically in the range of 3-14 V (0.06-0.28 $\mu \mathrm{A})$. Projection neurons recorded in the dorsal LA (see Fig. $1 A$ ) were discriminated from interneurons, which exhibit a fast firing frequency and little spike frequency adaptation. EPSCs analyzed in this study had constant and short delays, and the initial slopes were smoothly graded as a function of stimulus intensity, indicating monosynaptic events. Both picrotoxin (PTX; $40 \mu \mathrm{M})$ [and in some cases, bicuculline (10 $\mu \mathrm{M})]$ and (2S)-3-[[(15)-1-(3,4-dichlorophenyl)ethyl] amino2-hydroxypropyl] (phenylmethyl)phosphinic acid (CGP55845) (1 $\mu \mathrm{M})$, were present in the external solution to block $\mathrm{GABA}_{\mathrm{A}}$ and presynaptic and postsynaptic $\mathrm{GABA}_{\mathrm{B}}$ receptors, respectively. Cesium in the recording pipette blocked postsynaptic $\mathrm{GABA}_{\mathrm{B}}$ conductance internally. The NMDA receptor-mediated component of the EPSC (NMDA-EPSC) was recorded in the presence of the AMPA antagonist 2,3-dihydroxy-6-nitro-7-sulfonylbenzo[f]quinoxaline (NBQX) or 6-cyano-7-nitroquinoxaline-2,3-dione (CNQX) and in $\mathrm{Mg}^{2+}$-free perfusing solution to remove the voltagedependent $\mathrm{Mg}^{2+}$ block of the NMDA receptor. In the paired-pulse paradigm, the first conditioning response (EPSC1) and the second, or test response (EPSC2), were elicited in thalamic afferents at intervals of 35-
200 msec. The amplitude of the tail of the first EPSC at the time that the second EPSC was initiated was subtracted, and the percentage of facilitation was calculated according to the following formula: [(EPSC2 EPSC1)/EPSC1] $\times 100$. The percentage of facilitation was plotted as a function of the interstimulus interval (ISI) for naive, unpaired, and fearconditioned rats. The one-half fall time of NMDA EPSCs was measured as the time required to fall to one-half peak EPSC amplitude.

Drug application. Drugs were applied via superfusion in the ACSF except for NMDA application. In this case, the drug was drop-applied to the input of the chamber to diffuse homogeneously into the chamber. Because NMDA receptors desensitize, 25-35 min of recovery time was always allowed between drug applications. To minimize variability of NMDA-induced current from cell to cell, perfusion flow rate was kept constant, and the various drug concentrations were tested on each cell. Bath perfusion of NMDA was monitored frequently with green dye. The drugs NBQX, PTX, and NMDA were purchased from Research Biochemicals International (Natick, MA). D-2-amino-5-phosphonovaleric acid (D-APV), CGP55845, and ifenprodil were purchased from Tocris Cookson (Bristol, UK), and tetrodotoxin (TTX) was purchased from Sigma (St. Louis, MO).

Fear conditioning. Fear conditioning was measured with a San Diego Instruments (San Diego, CA) potentiated startle system using the potentiated startle paradigm adapted from Campeau and Davis (1992). The conditioning chamber was soundproof and was illuminated with a dim light (13 W lamp). The chamber contained a horizontal Plexiglas cylinder of $70 \mathrm{~mm}$ diameter and $155 \mathrm{~mm}$ length. Its grid floor was composed of seven stainless-steel rods $3 \mathrm{~mm}$ in diameter spaced $4.5 \mathrm{~mm}$ apart. An accelerometer located beneath the conditioning chamber measured displacement in response to a startle stimulus. Rats were habituated to the chamber for $5 \mathrm{~min}$ before each session, and baseline startle was measured in response to 30 presentations of a $50 \mathrm{msec}, 95 \mathrm{~dB}(<1 \mathrm{msec}$ rise-fall time) white-noise burst (startle burst). Startle amplitude was defined as peak accelerometer voltage within $200 \mathrm{msec}$ after startle stimulus onset. During training, a conditioned auditory stimulus $(3.7 \mathrm{sec}, 70 \mathrm{~dB}$ whitenoise tone, filtered at $2 \mathrm{kHz}$ with $24 \mathrm{~dB}$ /octave attenuation) was paired with an unconditioned stimulus (UCS) (0.5 mA footshock, $0.5 \mathrm{sec}$ duration) 10 times per day for $2 \mathrm{~d}$. On the third day, the rats were tested using 10 startle stimuli to habituate the animals followed by 20 additional startle stimuli, 10 of which were preceded by the conditioned stimulus (CS) (3.7 sec of $70 \mathrm{~dB}$ tone). Fear-potentiated startle was defined as percentage change in startle amplitude with and without the CS and calculated as: [(CS + startle burst) amplitude - amplitude of startle burst alone] amplitude of startle burst alone. In the unpaired control group, the conditioned and unconditioned stimuli were applied pseudorandomly 10 times per day for $2 \mathrm{~d}$ and tested in the same paradigm as the paired fear-conditioned animals. A series of experiments were performed in a blinded manner, but there was no difference in the results and the data were pooled.

Western blotting and antibodies. The lateral, basolateral, and central nuclei of the amygdala tissues were dissected in the presence of protease inhibitor cocktail (PIC) consisting of $1 \mathrm{~mm} 4$-(2-aminoethyl)benzenesulfonyl fluoride, $15 \mu \mathrm{m}$ pepstatin A, $14 \mu \mathrm{M}$ E-64, $40 \mu \mathrm{m}$ bestatin, $22 \mu \mathrm{m}$ leupeptin, and $0.8 \mu \mathrm{M}$ aprotinin. The dissected tissue was frozen in dry ice and stored at $\times 70^{\circ} \mathrm{C}$ until homogenization. Frozen amygdala tissues were homogenized in cold $\left(4^{\circ} \mathrm{C}\right)$ modified radioimmunoprecipitation assay buffer, which contained $50 \mathrm{~mm}$ Tris, $150 \mathrm{~mm} \mathrm{NaCl}, 1 \% \mathrm{NP}-40,0.5 \%$ Na-deoxycholate, $0.1 \%$ SDS, and PIC. Homogenates were centrifuged twice at $10,000 \times g$ for $10 \mathrm{~min}$ at $4^{\circ} \mathrm{C}$. The supernatant was collected and stored at $-70^{\circ} \mathrm{C}$ until use. Protein concentrations of the whole-cell lysates were determined using the DC protein assay kit (Bio-Rad, Hercules, CA). Equal amounts of protein ( $30 \mu \mathrm{g}$ for NR1, NR2A, and NR2B) were separated by $7.5 \%$ SDS-PAGE (w/v) and transferred onto a polyvinylidene difluoride membrane. After blocking with 5\% nonfat milk in TBSTween 20 buffer, the transferred membrane was then incubated for $1.5 \mathrm{hr}$ at room temperature with the primary antibodies at 1:1500 for NR1, 1:2000 for phosphorylated-NR1 (phospho-NR1; Upstate Biotechnology, Lake Placid, NY), 1:1500 for NR2A and NR2B, or at 1:1000 for actin (Santa Cruz Biotechnology, Santa Cruz, CA). The blots were washed four times each for $10 \mathrm{~min}$ in TBS-Tween 20 buffer and then incubated in 
horseradish peroxidase-conjugated goat anti-rabbit IgG (1:3000 for NR1 and 1:5000 for phospho-NR1; Upstate Biotechnology) or donkey antigoat IgG (1:3000 for NR2A and NR2B; 1:2000 for actin; Santa Cruz Biotechnology) for $1.5 \mathrm{hr}$ at room temperature. The bands were visualized by enhanced chemiluminescence (ECL Plus; Amersham Biosciences, Arlington Heights, IL) and quantified by densitometry using Lynx V software. Pilot experiments indicated that the protein loaded on the gel was within the linear range of the band density. To control for variability in sample loading and protein concentrations between samples, the ratio of densities of different glutamate receptors to actin was used to compare values between samples. The actin density levels did not change in fear conditioning. The ratio for densities of naive control values was defined as $100 \%$, and the ratio for those of different experimental groups was reported as a percentage of naive control.

Data analysis and statistics. All values were given as mean \pm SEM; error bars in the figures also represent SEM. Traces shown in the figures represent averages of 5-10 consecutive sweeps. Each value for EPSC amplitude in input-output plots represented means from five consecutive EPSCs. Peak EPSC amplitude was measured as the peak inward current within a time window defined as current onset to return to baseline. All antagonists were applied via superfusion in the ACSF and allowed at least 15-20 min to establish equilibrium in the brain slice. $\mathrm{Mg}^{2+}$-free solution was superfused for $40 \mathrm{~min}$ before recording to attempt to maximize $\mathrm{Mg}^{2+}$ washout. Data from control and drug-treated conditions or the effects of drugs in control and fear-conditioned animals were compared using paired Student's $t$ tests, two-way ANOVA, or Mann-Whitney tests. Statistical significance was defined at the level of $p<0.05$. For immunoblot analysis, differences between groups of naive control, unpaired control, and fear-conditioned animals were compared using ANOVA followed by a Tukey post hoc comparison whenever applicable. The difference was considered significant when $p<0.05$.

\section{Results}

In these studies, we used fear-potentiated startle as a measure of learned fear. Animal startle in response to a white-noise burst was tested and rats were subsequently trained to associate a tone (CS) with a footshock (UCS). Startle was measured $24 \mathrm{hr}$ later alone or preceded by the CS (Fig. $1 B$ ). When the CS and UCS were not paired during training, animals' startle responses on presentation of the CS were not altered $(-15 \pm 5 \% ; n=34)$, whereas in animals trained to associate the CS with the footshock, startle magnitude was increased ( $103 \pm 7 \% ; n=140$; $p<0.0001$; unpaired $t$ test; Mann-Whitney). In this paper, we defined the term "expression" as the behavior occurring during testing and defined "maintenance" as the period $24-48 \mathrm{hr}$ after learning and/or testing has occurred. Twenty-four hours after testing and $48 \mathrm{hr}$ after the last training, NMDA receptor-mediated EPSCs were recorded in neurons in the lateral amygdala in the presence of an AMPA glutamate receptor antagonist, NBQX (5 $\mu \mathrm{M})$, in $\mathrm{Mg}^{2+}$ free solution (Fig. 2A). The maximum amplitudes for NMDA EPSCs recorded in neurons from three groups of rats, $91.3 \pm 4.3$ pA $(n=16$, naive control), $72.3 \pm 9.3 \mathrm{pA}(n=14$, unpaired control), and $84.7 \pm 2.1 \mathrm{pA}(n=15$, fear-conditioned) were not significantly different among the animal populations (Student's unpaired $t$ test; $p>0.05$ ). When output current (in picoamperes) was plotted as a function of input stimulation (in volts) (Fig. 2A) for data in neurons from the three experimental groups, fearconditioned (FC), unpaired (UP) control, and naive (N) control, the slope of the lines did not differ between the three groups $\left(F_{(2,21)}=0.15 ; p=0.86\right)$. We also examined the effect of the NMDA receptor antagonist D-APV in normal ACSF to determine the contribution of the NMDA receptor to the composite EPSC. The plot of the output EPSC current versus stimulus intensity (Fig. $2 B)$ with and without APV $(25 \mu \mathrm{M})$ showed that EPSCs in neurons from $\mathrm{N}$ and UP control animals had significant APVsensitive components, whereas APV had no significant effect on

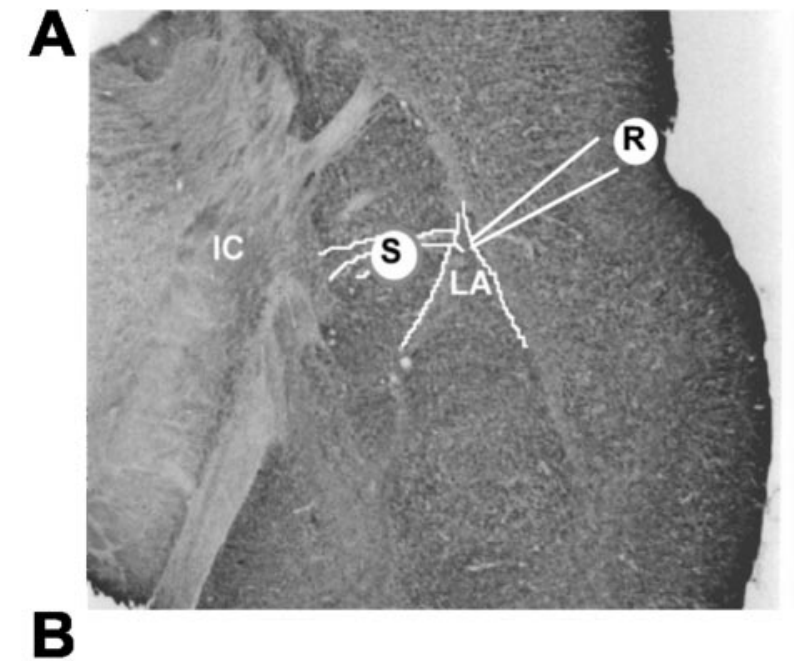

Acclimation/ Training

Training

Testing

In vitro

Day 1

2

3

4

Figure 1. Location of stimulating and recording electrodes in the amygdala slice preparation and experimental time line. $A$, Diagram of placement of stimulating $(S)$ and recording electrodes $(\mathrm{R})$ electrodes in a coronal section of rat brain modified from the atlas of Paxinos and Watson (1998). IC, Internal capsule. B, Time line for experimental fear conditioning paradigm and in vitro experiments.

EPSCs in amygdala neurons from FC animals $\left(\mathrm{N}: F_{(1,160)}=65.77\right.$, $p<0.0001$; UP: $F_{(1,120)}=198.42, p<0.0001 ; \mathrm{FC}: F_{(1,149)}=0.57$, $p=0.45$; two-way ANOVA). These data suggest that NMDA receptor-mediated synaptic transmission is not facilitated in fear conditioning. Furthermore, these results with NMDA EPSCs were significantly different from previous findings showing that AMPA receptor-mediated synaptic transmission and transmitter release probability are enhanced in fear conditioning (McKernan and Shinnick-Gallagher, 1997), particularly because presynaptic increases in transmitter release probability should be reflected as increases in both AMPA and NMDA receptor-mediated synaptic transmission.

To examine the differences in AMPA and NMDA EPSCs further, we measured NMDA synaptic currents in neurons from fear-conditioned animals compared with the two control groups using the paired-pulse paradigm as an index of transmitter release probability (Fig. $2 C$ ). In PPF, the second of two stimuli of equal magnitude evokes a larger synaptic response than the first, if the interval between the two pulses is sufficiently brief. PPF, originally proposed as measure of release probability (Del Castillo and Katz, 1954), is attributed to short-term changes in presynaptic calcium levels and is used as a tool to implicate changes in presynaptic transmitter release, because decreasing the external $\mathrm{Mg}^{2+} / \mathrm{Ca}^{2+}$ ratio, which increases the probability of release, causes decreases in PPF in a variety of preparations (Katz and Miledi, 1968; Manabe et al., 1993), including the amygdala (McKernan and Shinnick-Gallagher, 1997). Recently, Blatow et al. (2003) showed that PPF may also reflect calcium influx in terminals containing calbindin $28 \mathrm{k}$, an endogenous fast calcium buffer. The effects of fear conditioning on PPF of NMDA EPSCs were examined by applying pairs of stimuli at increasing ISIs ranging from 35 to $200 \mathrm{msec}$ (Fig. 2C). In these experiments, a significant group difference was found between fear-conditioned 

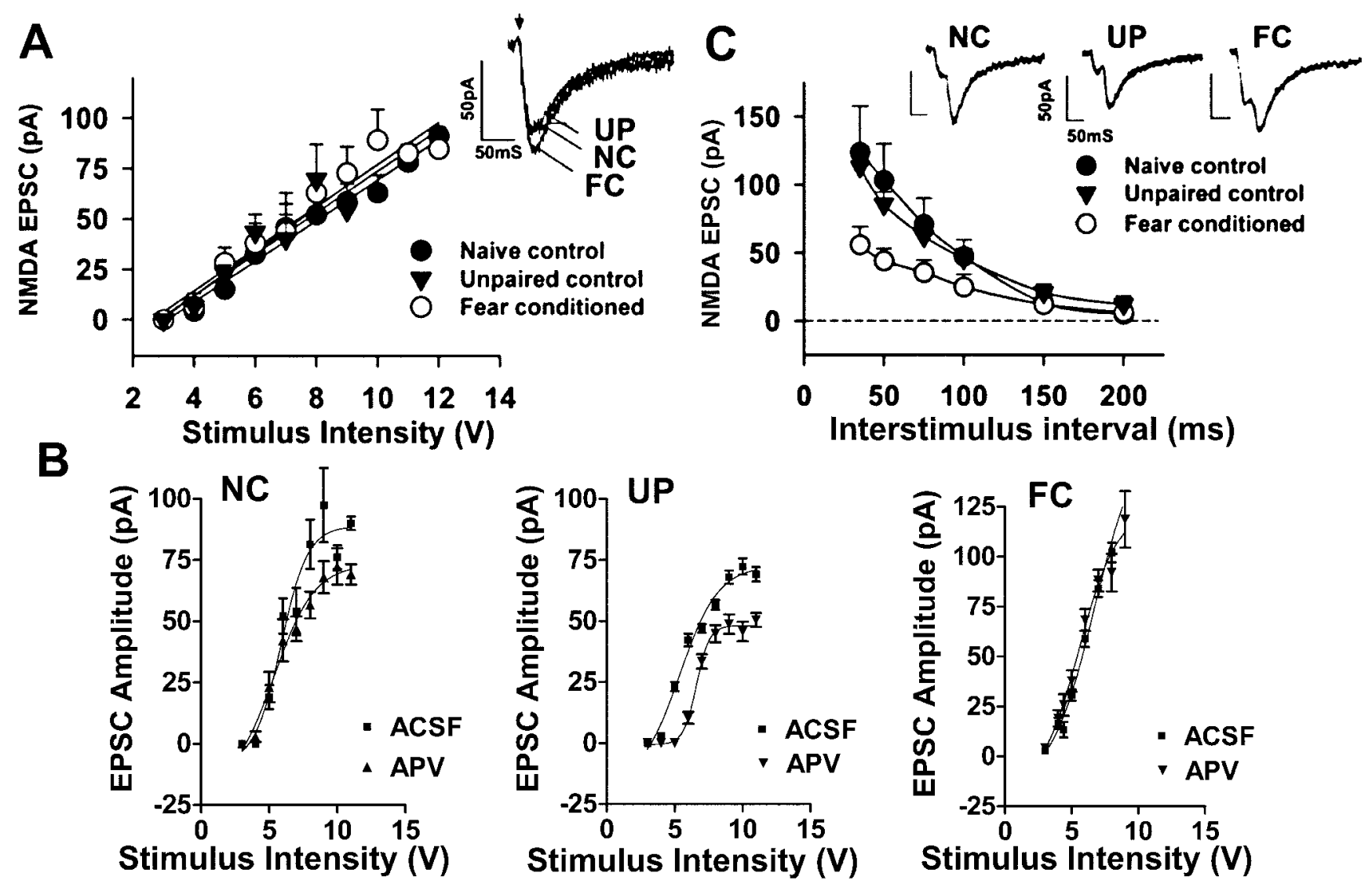

Figure 2. NMDA-mediated synaptic transmission is not altered in lateral amygdala neurons, and PPF of NMDA EPSCs is reduced in fear conditioning. $A$, NMDA EPSCs recorded in Mg ${ }^{2+}$-free ACSF and $5 \mu \mathrm{M} \mathrm{NBQX}$ are not changed in fear-conditioned animals. NMDA EPSC amplitudes are plotted as a function of stimulus intensity in neurons from both control (naive, filled circles; unpaired, filled triangles) and fear-conditioned (open circles) rats. The slopes of the lines were not significantly different ( $p>0.05)$ in neurons from the three populations of animals. Insets show superimposed traces of EPSCs in neurons from the different animal populations. B, The relationship between EPSC amplitude and stimulus intensity in control ACSF in the presence and absence of D-APV ( $25 \mu \mathrm{m}$ ) shows that the effect of APV is reduced in $\mathrm{FC}$ (right) compared with naive control (NC; left) and unpaired control (UP; middle) animals. Note that scales in the control groups are similar but are smaller in the FC group because of the large size of AMPA EPSCs in that group. C, PPF of the NMDA EPSC is decreased in lateral amygdala neurons from fear-conditioned rats. Percentage of facilitation is plotted as a function of interstimulus interval (in milliseconds). The horizontal dashed line is the 0 reference line. PPF is significantly decreased $(p<0.0001)$ in neurons from fear-conditioned animals compared with control (naive and unpaired) rats. Insets show traces of NMDA receptor-mediated PPF in lateral amygdala neurons from the three populations of animals at the same interstimulus interval $(35 \mathrm{msec}) \cdot V_{\mathrm{H}}=-60 \mathrm{mV}$.

and unpaired control or naive control animals $\left(F_{(2,90)}=11.03\right.$; $p<0.0001$; two-way repeated-measures ANOVA). The maximum PPF of NMDA EPSCs measured in naive rats was $123.8 \pm$ $33.8 \%$ at $35 \mathrm{msec}$ ISI, which decreased to $5 \pm 3 \%$ as the ISI reached $200 \mathrm{msec}$. The NMDA EPSCs in amygdala neurons from unpaired control rats had a maximum PPF of $113.23 \pm 9 \%$ at 35 msec ISI and $12 \pm 6 \%$ at $200 \mathrm{msec}$ ISI, values not different from those of naive rats. Neurons from fear-conditioned rats, however, showed a decrease in the maximum PPF measured at $35 \mathrm{msec}$ $(55.9 \pm 13 \%)$, whereas the PPF at $200 \mathrm{msec}(6.4 \pm 5 \%)$ was not different in the animal groups. Comparisons at the 35-100 msec interstimulus intervals revealed a significant treatment effect $\left[F_{(2,15)}=4.55 ; p<0.0002(35 \mathrm{msec}) ; F_{(2,15)}=17.75 ; p<0.0001\right.$ $(50 \mathrm{msec}) ; F_{(2,15)}=10.48 ; p<0.0017(75 \mathrm{msec}) ; F_{(2,15)}=9.12$; $p<0.0029$ (100 msec); one-way ANOVA], with neurons from fear-conditioned animals showing significantly less PPF than neurons from unpaired and naive control animals. This reduction was similar to that measured previously for AMPA receptormediated PPF (45\%) in lateral amygdala neurons from fearconditioned animals (McKernan and Shinnick-Gallagher, 1997). These data suggest that neurotransmitter release probability, as reflected in PPF of NMDA EPSCs, is enhanced after fear conditioning. These results also predicted that NMDA receptor- mediated transmission should be enhanced in fear conditioning, data incongruent with our findings, and suggested that other mechanisms are implicated in controlling NMDA receptormediated EPSCs in fear conditioning.

We analyzed postsynaptic mechanisms directly by applying NMDA exogenously to slices bathed in $\mathrm{Mg}^{2+}$-free solution containing NBQX ( $5 \mu \mathrm{M}$; to block AMPA receptors) and TTX ( $1 \mu \mathrm{M}$; to block voltage-activated sodium channels) (Fig. 3). The NMDA-induced inward current increased in a sigmoidal manner with increasing NMDA concentrations (specifically, 1, 2.5, 5, 10, 20,25 , and $50 \mu \mathrm{M}$ ) in neurons from fear-conditioned and control (unpaired and naive) rats. The plot of NMDA current as a function of concentration showed that the concentration-response curve for NMDA is shifted to the right in neurons from fearconditioned animals but not from the control animal groups. There was a significant treatment difference between NMDAinduced current in slices from fear-conditioned and naive rats or unpaired control rats $\left(F_{(2,142)}=4.68\right.$; two-way ANOVA; $p<$ $0.01)$. The $\mathrm{EC}_{50}$ values were shifted from 3.4 to $4.9 \mu \mathrm{M}$ for naive controls and unpaired controls, respectively, to $14.8 \mu \mathrm{M}$ for fearconditioned animals. In contrast, there was no significant difference between the maximum NMDA $(75 \mu \mathrm{M})$-induced current in naive $(401.3 \pm 84 \mathrm{pA})$, unpaired $(352.6 \pm 51 \mathrm{pA})$, or fear- 


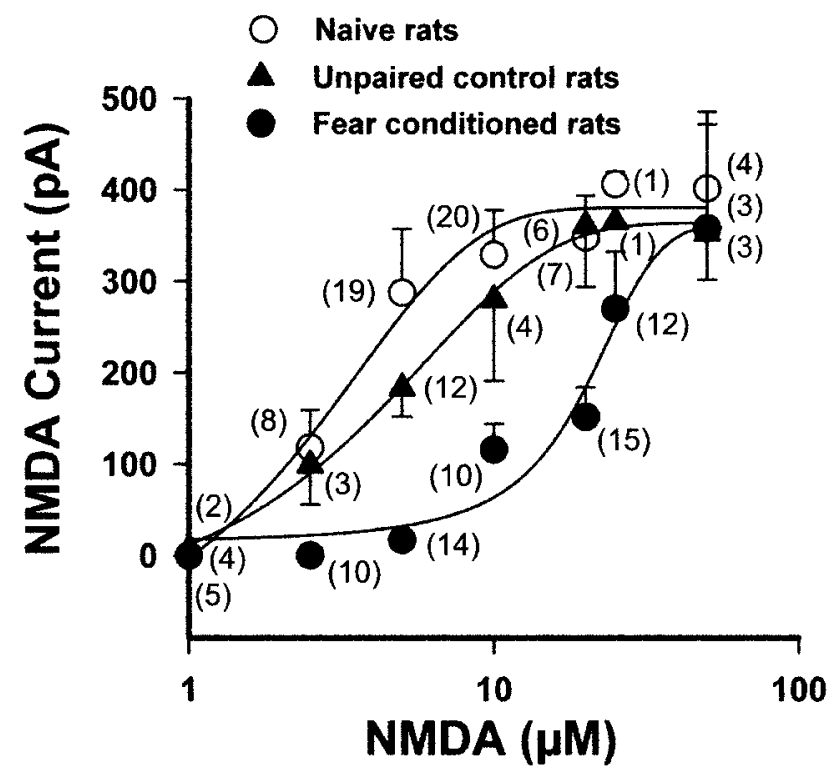

Figure 3. Concentration-response relationship for NMDA-induced currents is shifted to the right in projection neurons in the lateral amygdala of fear-conditioned animals (filled circles), compared with naive (open circles) and unpaired (filled triangles) control animals. Responses are elicited by drop-applying different concentrations of NMDA to the input of the recording chamber in $\mathrm{Mg}^{2+}$-free ACSF in the presence of $5 \mu \mathrm{m} \mathrm{NBQX} \mathrm{(to} \mathrm{block} \mathrm{AMPA} \mathrm{receptors)} \mathrm{and} 1 \mu \mathrm{M}$ TTX (to block action potential-dependent neurotransmitter release) $\left(V_{H}=-64 \mathrm{mV}\right)$. A washout period of $15 \mathrm{~min}$ (for low concentrations) to $35 \mathrm{~min}$ (for high concentrations) is allowed between applications. NMDA-induced current in unpaired control rats is not significantly different from naive rats but is significantly different from fear-conditioned animals. There is also a significant difference in NMDA-induced current recorded in neurons from naive control and fear-conditioned rats. Data are expressed as mean \pm SEM NMDA current. Numbers in parentheses are the number of data points for each mean value.

conditioned $(357.8 \pm 113 \mathrm{pA})$ rats. The response at the low concentrations of NMDA $(2.5 \mu \mathrm{M})$ was smaller in neurons from fear-conditioned rats $(0.28 \pm 0.1 \mathrm{pA})$ compared with those in naive $(118.2 \pm 40.9 \mathrm{pA})$ or unpaired $(98.8 \pm 43.4 \mathrm{pA})$ control animals. Responses at the plateau of the concentration-response relationship induced by maximal concentrations were not reversible because of excitotoxic effects of NMDA. Because the NMDA response was still smaller in neurons from fear-conditioned rats than in those from the control groups at low concentrations of agonist $(2.5 \mu \mathrm{M})$, in which excitotoxicity is less apt to occur, it is unlikely that toxic effects of NMDA receptor activation could account for the differences. These data suggest that the postsynaptic receptors activated by exogenous NMDA are altered in fear conditioning.

NMDA applied exogenously can activate both synaptic and nonsynaptic receptors. To assess the functional responsiveness of synaptic NMDA receptor subunits to endogenously released glutamate, we analyzed the effect of ifenprodil (Fig. 4), an antagonist for NR2B-containing NMDA receptors (Williams, 1993). Ifenprodil reduced NMDA receptor-mediated EPSCs in neurons from unpaired control (36 $\pm 5 \%$ inhibition; $n=9)$ and fearconditioned $(11 \pm 7 \% ; n=12)$ animals, but the inhibitory effect of ifenprodil was significantly greater in the unpaired animal group (Mann-Whitney test; $p<0.006$ ). It is possible that the ifenprodil-resistant NMDA EPSC may reflect primarily NR2Amediated NMDA EPSC subunits (Fig. $4 B$ ), but ifenprodil produces only an $80 \%$ block of pure NR1/NR2B receptors (Tovar and Westbrook, 1999) and can potentiate rather than reduce responses at low concentrations of agonist (Kew et al., 1996;

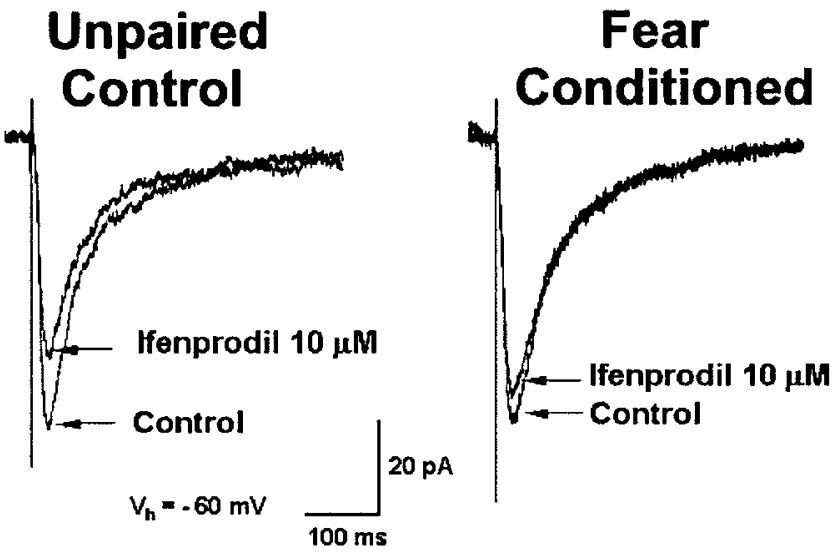

Figure 4. Inhibitory effect of ifenprodil on synaptic NMDA receptors is reduced in neurons from fear-conditioned animals. Ifenprodil ( $10 \mu \mathrm{M})$, an antagonist of the NR2B subunit, reduced NMDA EPSCs recorded in amygdala neurons from unpaired control rats but had a diminished effect in neurons from fear-conditioned animals. The NMDA component of the EPSC is isolated using the AMPA receptor antagonist CNQX in $\mathrm{Mg}^{2+}$-free ACSF. Stimulus intensity, $9 \mathrm{~V}$.

Zhang et al., 2000). Under these circumstances, the ifenprodil effect would underestimate NR2B subunits, overestimate NR2A subunits, and influence the accuracy of ratios derived from EPSCs. Nonetheless, these results suggest that, after fear conditioning, NR2B subunits are reduced at the subsynaptic membrane.

To analyze further NMDA receptor subunit composition, we used Western blotting to measure NR1, NR2A, NR2B, and phosphorylated-NR1 protein prepared from the amygdalas of naive control, unpaired control, and fear-conditioned animals. Western blotting showed that the NR2B subunit was not significantly changed in unpaired control $[81.06 \pm 18.47$ optical density (OD)] compared with naive control (100 \pm 15.12 OD; $p>$ 0.05 ) animals. However, NR2B protein was reduced $67 \%$ in amygdalas obtained from fear-conditioned rats (Fig. 5C,D) $\left(32.86 \pm 4.05 \mathrm{OD} ; n=12 ; F_{(2,23)}=4.9 ; p<0.05\right.$; one-way ANOVA; post hoc Tukey test). NR2A protein in amygdalas from fear-conditioned animals was also significantly decreased (Fig. $5 A, B)(49.73 \pm 8.7 \mathrm{OD})$ compared with that in naive control $(100 \pm 15.14 \mathrm{OD})$ and unpaired control $(88.38 \pm 19.27 \mathrm{OD}$; $F_{(2,22)}=3.7 ; p<0.04$; ANOVA; post hoc Tukey test) animals. These data suggest that there is a consistent downregulation of NR2B and NR2A subunit protein in the amygdala as a result of fear learning.

In the visual system, changes in the kinetics of the NMDA EPSC (Carmignoto and Vicini, 1992) are thought to reflect changes in the NR2A/NR2B subunit ratio (Quinlan et al., 1999). We analyzed whether changes in the NMDA subunits and NMDA EPSC rise times (RTs) and decay times (DTs) were correlated in the amygdala in fear conditioning. We compared the ratios of NR2A protein with NR2B protein and found no significant difference in the NR2A/NR2B ratios in the amygdala obtained from the different animal groups (unpaired control, $0.85 \pm 0.49, n=6$; fear-conditioned, $0.91 \pm 0.1, n=10 ; F_{(2,20)}=$ $1.564 ; p=0.23$; one-way ANOVA). These results suggest that the NR2A/NR2B ratios are not changed with fear conditioning.

Electrophysiological analyses of the RTs and DTs of the NMDA EPSCs in neurons from unpaired and fear-conditioned animals (unpaired RT, $10.5 \pm 1.0 \mathrm{msec}$; unpaired DT, $132.3 \pm$ $14.7 \mathrm{msec} ; n=7$; fear-conditioned RT, $15.2 \pm 2.5 \mathrm{msec}$; fearconditioned DT, $177.9 \pm 27.9 \mathrm{msec} ; n=10$ ) were also not sig- 
nificantly different $(\mathrm{RT}, t=1.527, \mathrm{df}=15$, $p=0.15$; DT $, t=1.271, \mathrm{df}=15, p=0.22$; unpaired $t$ test). These data indicate that neither the ratios of receptor protein in amygdala nuclei nor the electrophysiological measures of the kinetics of synaptic potentials show significant changes in neurons from fear-conditioned animals and suggest that change in the duration of NMDA synaptic potentials may not contribute to the maintenance of fear memory.

Because the presence of the NR1 subunit protein is essential for functional activity of the heteromeric NMDA receptor (Monyer et al., 1992; Ishii et al., 1993), we hypothesized that NR1 subunit protein in the three populations of animals would differ, but we found that the NR1 subunit protein was not affected by fear conditioning (Fig. 6A,B) (naive, $100 \pm 9.9$ OD; unpaired, $114.41 \pm 11.26 \mathrm{OD}$; fearconditioned, $98.2 \pm 9.28 \mathrm{OD} ; n=8 ; p>$ $0.05)$. Because phosphorylation of the NMDA receptor enhances the functional activity of the receptor (Chen and Huang, 1992), we also probed for changes in the phosphorylated-NR1 subunit protein. Our results show that phospho-NR1 is significantly reduced in amygdalas from fear-conditioned animals compared with those from naive and unpaired rats (Fig. 6C,D) (naive, $100 \pm 16 \mathrm{OD}$; unpaired, $87.8 \pm 11.07 \mathrm{OD}$; fearconditioned, $43.6 \pm 6.97 \mathrm{OD} ; n=6 ; F_{(2,15)}=6.16 ; p<0.01$; one-way ANOVA). A reduction in phosphorylated NMDA receptors would result in a functional decrease in NMDA receptormediated responsiveness (Chen and Huang, 1992), which is consistent with our electrophysiological findings in lateral amygdala neurons showing that responses to NMDA are reduced in fearconditioned animals.

\section{Discussion}

Evidence for altered NR subunits

The primary finding of this study is that NR subunits are functionally downregulated $48 \mathrm{hr}$ after fear learning during the maintenance phase of the behavioral memory trace. This conclusion is supported by the following data: (1) the NMDA receptormediated EPSC was not facilitated in fear conditioning and the APV-sensitive portion of the EPSC was reduced; (2) ifenprodil, a selective antagonist of NR2B subunits, has a diminished effect on NMDA EPSCs in neurons from fear-conditioned animals; (3) responses to exogenously applied NMDA were reduced and the $\mathrm{EC}_{50}$ values for NMDA receptor-mediated currents shifted threefold to fourfold to the right after fear conditioning; and (4) expression of phospho-NR1, NR2A, and NR2B subunit proteins was reduced in amygdalas from fear-conditioned animals. These studies provide the first evidence that NMDA receptors are functionally downregulated at synapses as a result of fear learning and suggest that this is attributable to a reduced amount of phosphoNR1, NR2A, and NR2B subunit protein.

Both presynaptic and postsynaptic changes in NMDA receptor-mediated transmission are recorded after fear conditioning. Phospho-NR1, NR2A, and NR2B NMDA receptorchannel protein was reduced in fear-conditioned rats, and that reduction could underlie the decrease in NMDA-activated current. In contrast, the NR1 subunit was not decreased. Because NMDA subunits have different gene assignments (Hollmann and Heinemann, 1994), differential regulation of subunits is possible. The binding site for glutamate is on the NR2 (Laube et al., 1997) rather than the NR1 subunit, suggesting that glutamate released during training may have more influence on those subunits. It is also possible that there is a significant store of NR1 subunits and that NR2 subunits have a smaller reserve store, permitting susceptibility to fear-conditioning-induced changes. A functional reduction in NR2B subunits was also recorded at the subsynaptic membrane as a reduced effect of ifenprodil on fear conditioning. Furthermore, the APV-sensitive portion of the EPSC was reduced, suggesting postsynaptic modifications in neurons from fear-conditioned animals. However, PPF measured with composite EPSCs, AMPA EPSCs (McKernan and ShinnickGallagher, 1997), and NMDA EPSCs is reduced at these synapses, suggesting that transmitter release probability is enhanced in fear conditioning. Under the low $-\mathrm{Mg}^{2+}$ recording conditions shown in Figure $2 A$, it is likely that the depression of NMDA receptormediated EPSCs was masked because both low $\mathrm{Mg}^{2+}$ and fear conditioning cause enhanced transmitter release, whereas the decrease in synaptic NMDA receptors was reflected in the reduced effects of ifenprodil and APV after fear conditioning (Figs. $2 B$, $4 A, B)$. An operational mechanism for NMDA-mediated transmission in the maintenance of fear memory may be that presynaptic increases in transmitter release probability (McKernan and Shinnick-Gallagher, 1997) are offset by reduced functioning of the postsynaptic NMDA receptor-channel.

\section{Large change, important memory?}

How can the measured changes in NR subunit protein in fear conditioning be large if, presumably, they are restricted to a small subset of synapses that hold the memory trace? It is likely that the conditioning event is not a trivial memory for animals, because it 

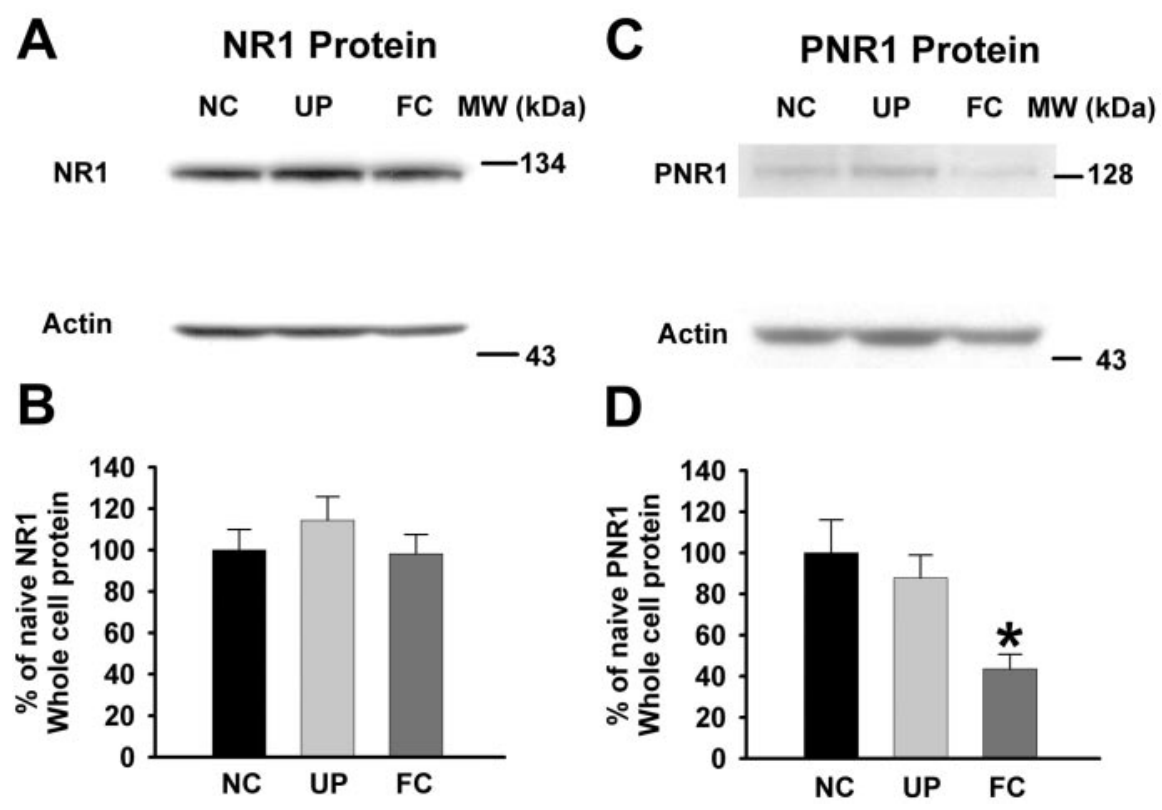

Figure 6. Expression of phosphorylated-NR1 (PNR1) but not NR1 subunit protein is decreased in fear conditioning. $A$, Representative Western blots for NR1 subunits having a molecular weight (MW) of $\sim 130 \mathrm{kDa}$ show that NR1 expression is not significantly altered in amygdalas from fear-conditioned rats. $B$, Bar graphs show that the NR1 subunit is not changed in amygdalas from FC animals ( $n=8 ; p>0.05)$ compared with those from naive control (NC; $n=8)$ and UP $(n=8)$ rats. The NR1 proteins from unpaired and fear-conditioned rats are shown as a percentage of those from naive rats. $C$, Representative Western blots of PNR1 from amygdalas of naive control, unpaired control, and fear-conditioned animals. PNR1 subunit expression appears at $\sim 130 \mathrm{kDa}$ and shows a reduced expression in amygdalas from fear-conditioned animals. D, Bar graphs summarizing the expression of PNR1 protein from the amygdalas of the three populations of animals. PNR1 expression in the unpaired control and fear-conditioned group is expressed as a percentage of the naive control group. Protein expression of PNR1 was significantly decreased in FC animals $\left(n=6\right.$; $\left.{ }^{*} p<0.05\right)$ compared with NC $(n=6)$ and UP $(n=6)$ animals.

is linked to systems underlying their very survival. It is thought that these events should be selective to only a few neurons, but some anatomical data indicate that larger numbers of amygdala neurons are affected after fear conditioning (Stanciu et al., 2001), suggesting that the subsets of cells involved may be larger than expected. Furthermore, recent anatomical data show that the amygdaloid complex is a neuronal network having reciprocal connections (Pitkanen, 2000; Pitkanen et al., 2003); this circuitry raises the possibility of a CS amplification mechanism during fear conditioning.

\section{Is NMDA transmission similar in behavioral fear conditioning and LTP?}

Fear conditioning is thought to model learning processes of fear as well as some features of cue-induced anxiety (Goddard and Charney, 1997). Fear learning has many properties similar to LTP (LeDoux, 2000), but one difference in these processes may be that the expression of fear learning but not LTP is blocked by NMDA receptor antagonists (Fendt, 2001; Lee et al., 2001) (but see Miserendino et al., 1990; Maren et al., 1996; Rodrigues et al., 2001; Walker and Davis, 2002). It is thought that the sensitivity of fear expression to NMDA receptor antagonists is attributable to the block of NMDA receptors involved in the normal aspects of transmission and not plasticity (LeDoux, 2000) (but see Gewirtz and Davis, 1997), the involvement of specific subunits in acquisition but not expression of fear conditioning (Rodrigues et al., 2001), or the time of antagonist administration between fear learning and fear testing (Walker and Davis, 2000). The present data provide a membrane mechanism for modulation of NMDA receptors that could contribute to the maintenance of fear memories in auditory fear-conditioning pathways.

Many processes involved in learning and memory are dependent on NMDA receptors for their induction mechanisms, but the function of NMDA receptors during the maintenance phase of those events has received relatively little attention. LTP can cause rapid surface expression of NR1, NR2A, and NR2B rather than AMPA subunits in adult animals, an effect that persists for $3 \mathrm{hr}$ (Grosshans et al., 2002). Tyrosine phosphorylation of NR2B is facilitated for 3-24 hr after electrically induced LTP in the hippocampus in vivo (Rosenblum et al., 1996; Rostas et al., 1996) and in the cortex after conditioned taste aversion (Rosenblum et al., 1997). Furthermore, after spatial maze training, association of NMDA receptors with src protein tyrosine kinase is enhanced (Zhao et al., 2000), but phosphorylated-NR2 protein returns to normal in $24 \mathrm{hr}$. In addition, removal of NR1 in hippocampal CA1 neurons in inducible knock-out mice 21-29 d after training does not affect cued fear conditioning (Shimizu et al., 2000) (but see Day and Morris, 2001), suggesting that NMDA receptors are not required for the maintenance of the behavioral memory trace. These studies of NMDA receptors in LTP and behavior do not endorse a role for NMDA receptors in behavioral memory persisting for $>24 \mathrm{hr}$, the generally accepted time frame for maintenance of behavioral long-term memory (Dudai, 2002); rather, they lend support to our finding that NMDA receptors are downregulated in the maintenance of fear memory.

\section{Functional relevance}

How does a reduction in NMDA EPSCs, NMDA-induced current, and NR protein relate to persistence of long-term memory? Nader et al. (2000) showed that protein synthesis inhibitors given $24 \mathrm{hr}$ to $14 \mathrm{~d}$ after training had no effect on subsequent retrieval of fear memory, suggesting that the time frame used in our studies, $24 \mathrm{hr}$ after testing, represents a stable maintenance phase of fear memory. Recently, Dudai (2002) proposed that persistence of long-term memory might not represent an active state but rather the "capacity to reactivate." In our studies, downregulation of NMDA subunits may represent the capacity to reactivate or retrieve memories. The present data suggest that there is a greater capacity to reactivate NR2 subunits and phosphorylate NR1 subunits. Memory retrieval may induce NR2 subunits to form heteromeric receptors with NR1 subunits to reactivate the memory. Alternatively, downregulation of NMDA receptors may represent a compensatory state, because if NMDA receptors were to remain upregulated, as they are after in vitro LTP induction (Bashir et al., 1991; Gean et al., 1993; Grosshans et al., 2002), the potential for excitotoxicity would increase, suggesting that downregulation of NMDA receptors in the maintenance of memory could be a protective mechanism. Additionally, the decrease in NMDA synaptic transmission may indicate a long-term depression (LTD)-like mechanism. Simultaneous LTP of AMPA 
receptor-mediated responses and LTD of NMDA receptormediated responses are reported in vitro in certain brain nuclei (Kombian and Malenka, 1994). Similarly, after fear conditioning, persistent LTP of AMPA receptor-mediated transmission (McKernan and Shinnick-Gallagher, 1997) may occur with an enduring LTD of NMDA receptor-mediated transmission.

The role of NMDA receptors in expression of auditory fear conditioning has been controversial (Miserendino et al., 1990; Campeau et al., 1992; Maren et al., 1996; Fendt, 2001; Lee et al., 2001). Some studies have shown that intra-amygdala infusion of NMDA antagonists enhances expression of fear-potentiated startle (Campeau et al., 1992; Gewirtz and Davis, 1997). If enhanced startle results from the block of NMDA receptors, the reduced NMDA receptor transmission measured here may contribute to this effect of the antagonists. Interestingly, new fear learning in previously fear-conditioned animals requires amygdala NMDA receptors (Lee and Kim, 1998). Similarly, extinction of fearpotentiated startle is blocked by infusion of an NMDA antagonist into the amygdala (Falls et al., 1992). The requirement of amygdala NMDA receptors for new fear learning (Lee and Kim, 1998) or for extinction (Falls et al., 1992) occurs in previously fearconditioned animals, the time point analyzed in the present study. The reduction in NMDA EPSCs, NMDA-induced current, and NR protein may be important to the subsequent laying down of new memory engrams dependent on NMDA receptors as part of a cycling process. Initially, NMDA receptors may be upregulated as needed during memory induction and downregulated to maintain the capacity to reactivate (Dudai, 2002).

In summary, our data suggest that NMDA receptor-mediated neurotransmission is reduced in the maintenance phase of fear memory, and that these changes are attributable to a reduced synaptic expression of NMDA receptor protein. This reduction in NMDA receptor-mediated transmission would have a substantial effect on synaptic plasticity and consequently on the functional engagement of the fear-conditioning neural network in the amygdala.

\section{References}

Bashir ZI, Alford S, Davies SN, Randall AD, Collingridge GL (1991) Longterm potentiation of NMDA receptor-mediated synaptic transmission in the hippocampus. Nature 349:156-158.

Bear MF (1996) NMDA-receptor-dependent synaptic plasticity in the visual cortex. Prog Brain Res 108:205-218.

Blatow M, Caputi A, Burnashev N, Monyer H, Rozov A (2003) $\mathrm{Ca}^{2+}$ buffer saturation underlies paired pulse facilitation in calbindin-D28kcontaining terminals. Neuron 38:79-88.

Campeau S, Davis M (1992) Fear potentiation of the acoustic startle reflex using noises of various spectral frequencies as conditioned stimuli. Anim Learn Behav 20:117-186.

Campeau S, Miserendino M, Davis M (1992) Intra-amygdala infusion of the $\mathrm{N}$-methyl-D-aspartate antagonist AP5 blocks acquisition but not expression of fear-potentiated startle to an auditory conditioned stimulus. Behav Neurosci 106:569-574.

Carmignoto G, Vicini S (1992) Activity-dependent decrease in NMDA receptor responses during development of the visual cortex. Science 258:1007-1011.

Chen L, Huang L (1992) Protein kinase C reduces $\mathrm{Mg}^{2+}$ block of NMDAreceptor channels as a mechanism of modulation. Nature 356:521-523.

Cull-Candy S, Brickley S, Farrant M (2001) NMDA receptor subunits: diversity, development and disease. Curr Opin Neurobiol 11:327-335.

Davis M (1992) The role of the amygdala in fear and anxiety. Annu Rev Neurosci 15:353-375.

Day M, Morris RG (2001) Memory consolidation and NMDA receptors: discrepancy between genetic and pharmacological approaches. Science 293:755.

Del Castillo J, Katz B (1954) Statistical factors in neuromuscular facilitation and depression. J Physiol (Lond) 124:574-585.
Dudai Y (2002) Molecular bases of long-term memories: a question of persistence. Curr Opin Neurobiol 12:211-216.

Errington M, Lynch M, Bliss TV (1987) Long-term potentiation in the dentate gyrus: induction and increased glutamate release are blocked by D-aminophosphonovalerate. Neuroscience 20:279-284.

Falls WA, Miserendino MJ, Davis M (1992) Extinction of fear-potentiated startle: blockade by infusion of an NMDA antagonist into the amygdala. J Neurosci 12:854-863.

Fendt M (2001) Injections of the NMDA receptor antagonist aminophosphonopentanoic acid into the lateral nucleus of the amygdala block the expression of fear-potentiated startle and freezing. J Neurosci 21:4111-4115.

Gean P-W, Chang F-C, Huang C, Lin J, Way L (1993) Long-term enhancement of EPSP and NMDA receptor-mediated synaptic transmission in the amygdala. Brain Res Bull 31:7-11.

Gewirtz JC, Davis M (1997) Second-order fear conditioning prevented by blocking NMDA receptors in amygdala. Nature 388:471-474.

Goddard AW, Charney DS (1997) Toward an integrated neurobiology of panic disorder. J Clin Psychiatry 58:4-11.

Grosshans DR, Clayton DA, Coultrap SJ, Browning MD (2002) LTP leads to rapid surface expression of NMDA but not AMPA receptors in adult rat CA1. Nat Neurosci 5:27-33.

Hollmann M, Heinemann S (1994) Cloned glutamate receptors. Annu Rev Neurosci 17:31-108.

Ishii T, Moriyoshi K, Sugihara H, Sakurada K, Kadotani H, Yokoi M, Akazawa C, Shigemoto R, Mizuno N, Masu M (1993) Molecular characterization of the family of the $N$-methyl-D-aspartate receptor subunits. J Biol Chem 268:2836-2843.

Katz B, Miledi R (1968) The role of calcium in neuromuscular facilitation. J Physiol (Lond) 195:481-492.

Kauer JA, Malenka RC, Nicoll RA (1988) A persistent postsynaptic modification mediates long-term potentiation in the hippocampus. Neuron 1:911-917.

Kew JN, Trube G, Kemp JA (1996) A novel mechanism of activitydependent NMDA receptor antagonism describes the effect of ifenprodil in rat cultured cortical neurones. J Physiol (Lond) 497:761-772.

Kohr G, Seeburg PH (1996) Subtype-specific regulation of recombinant NMDA receptor-channels by protein tyrosine kinases of the src family. J Physiol (Lond) 492:445-452.

Kombian SB, Malenka RC (1994) Simultaneous LTP of non-NMDA- and LTD of NMDA-receptor-mediated responses in the nucleus accumbens. Nature 368:242-246.

Lau LF, Huganir RL (1995) Differential tyrosine phosphorylation of $N$-methyl-D-aspartate receptor subunits. J Biol Chem 270:20036-20041.

Laube B, Hirai H, Sturgess M, Betz H, Kuhse J (1997) Molecular determinants of agonist discrimination by NMDA receptor subunits: analysis of the glutamate binding site on the NR2B subunit. Neuron 18:493-503.

Lavond DG, Kim JJ, Thompson RF (1993) Mammalian brain substrates of aversive classical conditioning. Annu Rev Psychol 44:317-342.

LeDoux J (2000) The amygdala and emotion: a view through fear. In: The amygdala: a functional analysis (Aggleton JP, ed), pp 289-310. Oxford: Oxford UP.

LeDoux JE, Ruggiero DA, Reis DJ (1985) Projections to the subcortical forebrain from anatomically defined regions of the medial geniculate body in the rat. J Comp Neurol 242:182-213.

Lee H, Kim JJ (1998) Amygdalar NMDA receptors are critical for new fear learning in previously fear-conditioned rats. J Neurosci 18:8444-8454.

Lee HJ, Choi JS, Brown TH, Kim JJ (2001) Amygdalar NMDA receptors are critical for the expression of multiple conditioned fear responses. J Neurosci 21:4116-4124.

MacDonald AJ (1998) Cortical pathways to the mammalian amygdala. Prog Neurobiol 55:257-331.

Manabe T, Wyllie D, Perkel DJ, Nicoll R (1993) Modulation of synaptic transmission and long-term potentiation: effects on paired pulse facilitation and EPSC variance in the $\mathrm{CA}_{1}$ region of the hippocampus. J Neurophysiol 70:1451-1459.

Maren S, Aharonov G, Stote DL, Fanselow MS (1996) N-methyl-Daspartate receptors in the basolateral amygdala are required for both acquisition and expression of conditional fear in rats. Behav Neurosci 110:1365-1374.

McKernan M, Shinnick-Gallagher P (1997) Fear conditioning induced long-lasting increases in amygdala synaptic efficacy. Nature 390:607-611. 
Miserendino MJD, Sananes CB, Melia KR, Davis M (1990) Blocking of acquisition but not expression of conditioned fear-potentiated startle by NMDA antagonists in the amygdala. Nature 345:716-718.

Monyer H, Sprengel R, Schoepfer R, Herb A, Higuchi M, Lomeli H, Burnashev N, Sakmann B, Seeberg PH (1992) Heteromeric NMDA receptors: molecular and functional distinction of subtypes. Science 256:1217-1221.

Monyer H, Burnashev N, Laurie D, Sakmann B, Seeburg P (1994) Developmental and regional expression in the rat brain and functional properties of four NMDA receptors. Neuron 12:529-540.

Muller D, Joly M, Lynch G (1988) Contributions of quisqualate and NMDA receptors to the induction and expression of LTP. Science 242:1694-1697.

Nader K, Schafe GE, Le Doux JE (2000) Fear memories require protein synthesis in the amygdala for reconsolidation after retrieval. Nature 406:722-726.

Nicoll RA, Malenka RC (1995) Contrasting properties of two forms of longterm potentiation in the hippocampus. Nature 377:115-118.

Nicoll RA, Malenka RC (1999) Expression mechanisms underlying NMDA receptor-dependent long-term potentiation. Ann NY Acad Sci 868:515-525.

Paxinos G, Watson C (1998) The rat brain in stereotaxic coordinates. San Diego: Academic.

Pitkanen A (2000) Connectivity of the rat amygdaloid complex. In: The amygdala-a functional analysis (Aggleton JP, ed), pp 31-115. Oxford: Oxford UP.

Pitkanen A, Savander M, Nurminen N, Ylinen A (2003) Intrinsic synaptic circuitry of the amygdala. Ann NY Acad Sci 985:22-49.

Quinlan EM, Olstein DH, Bear MF (1999) Bidirectional, experiencedependent regulation of $N$-methyl-D-aspartate receptor subunit composition in the rat visual cortex during postnatal development. Proc Natl Acad Sci USA 96:12876-12880.

Rodrigues SM, Schafe GE, LeDoux JE (2001) Intra-amygdala blockade of the NR2B subunit of the NMDA receptor disrupts the acquisition but not the expression of fear conditioning. J Neurosci 21:6889-6896.

Rogan M, Staubli U, LeDoux J (1997) Fear conditioning induces associative long-term potentiation in the amygdala. Nature 390:604-607.
Rosenblum K, Dudai Y, Richter-Levin G (1996) Long-term potentiation increases tyrosine phosphorylation of the $N$-methyl-D-aspartate receptor subunit $2 \mathrm{~B}$ in rat dentate gyrus in vivo. Proc Natl Acad Sci USA 93:10457-10460.

Rosenblum K, Berman DE, Hazvi S, Lamprecht R, Dudai Y (1997) NMDA receptor and the tyrosine phosphorylation of its $2 \mathrm{~B}$ subunit in taste learning in the rat insular cortex. J Neurosci 17:5129-5135.

Rostas JA, Brent VA, Voss K, Errington M, Bliss T, Gurd J (1996) Enhanced tyrosine phosphorylation of the $2 \mathrm{~B}$ subunit of the $N$-methyl-D-aspartate receptor in long-term potentiation. Proc Natl Acad Sci USA 93:10452-10456.

Shimizu E, Tang YP, Rampon C, Tsien JZ (2000) NMDA receptordependent synaptic reinforcement as a crucial process for memory consolidation. Science 290:1170-1174.

Stanciu M, Radulovic J, Spiess J (2001) Phosphorylated cAMP response element binding protein in the mouse brain after fear conditioning: relationship to Fos production. Brain Res Mol Brain Res 94:15-24.

Tovar KR, Westbrook GL (1999) The incorporation of NMDA receptors with a distinct subunit composition at nascent hippocampal synapses in vitro. J Neurosci 19:4180-4188.

Walker DL, Davis M (2000) Involvement of NMDA receptors within the amygdala in short- versus long-term memory for fear conditioning as assessed with fear-potentiated startle. Behav Neurosci 114:1019-1033.

Walker DL, Davis M (2002) The role of amygdala glutamate receptors in fear learning, fear-potentiated startle, and extinction. Pharmacol Biochem Behav 71:379-392.

Williams K (1993) Ifenprodil discriminates subtypes of the $N$-methyl-Daspartate receptor: selectivity and mechanisms at recombinant heteromeric receptors. Mol Pharmacol 44:851-859.

Zhang XX, Bunney BS, Shi WX (2000) Enhancement of NMDA-induced current by the putative NR2B selective antagonist ifenprodil. Synapse 37:56-63.

Zhao W, Cavallaro S, Gusev P, Alkon DL (2000) Nonreceptor tyrosine protein kinase pp60c-src in spatial learning: synapse-specific changes in its gene expression, tyrosine phosphorylation, and protein-protein interactions. Proc Natl Acad Sci USA 97:8098-8103. 